\title{
Modern and Vernacular Settlements in Doha: An Urban Planning Strategy to Pursue Modernity and Consolidate Cultural Identity
}

\section{Furlan $\mathbf{R}^{*}$}

Department of Architecture and Urban Planning, College of Engineering, Qatar University, State of Qatar, Doha

*Corresponding author: Furlan R, Department of Architecture and Urban Planning, College of Engineering, Qatar University, State of Qatar, Doha, Tel: +97444034100; E-mail: raffur@gmail.com

Received date: March 19, 2016; Accepted date: April 19, 2016; Published date: April 25, 2016

Copyright: (c) 2016 Furlan R. This is an open-access article distributed under the terms of the Creative Commons Attribution License, which permits unrestricted use, distribution, and reproduction in any medium, provided the original author and source are credited.

\begin{abstract}
Scholars and researchers, who investigate the extent to which spatial form and livability are mutually interconnected, stress that the built environment provides the space for the enhancement of social interactions, which in turn have a deep impact on the level of livability of cities.

Namely, in relation to this relationship, to which extent the built environment of (1) the contemporary business district of 'West Bay' and (2) of the heritage site of the 'Souq Waqif' in Doha contributes to the enhancement of social interactions and/or livability has not been comparatively investigated yet. This study aims at investigating how the spatial form of the two selected precincts contributes to create a livable environment.

The analysis indicates that while West Bay's contemporary built environment contributes to the image of Doha as a modern city, the traditional settlement of the Souq Waqif contributes to the formation of a sense of community, increase occasions for social interactions, enhance livability and finally consolidate cultural identity.
\end{abstract}

Keywords: Globalization; Vernacular settlements; Doha; Livability

\section{Introduction}

In the past two decades, due (1) to a significant growth in national wealth, produced by the production and export of oil and gas, (2) to globalization or westernization as a world-wide trend and finally (3) to the resulting desire to attract foreigners to invest into the rapid and intense urban development of GCC capital cities', Middle Eastern countries has experienced the construction of modern districts exposing spectacular structures influenced by western-contemporary architectural design, materials and construction techniques. This trend, experienced by GCC capital cities, contributed to the expansion of single core cities towards decentralized new urban neighborhood.

Scholars and researchers argue that in the past years Arab cities has witnessed the construction of more western developments than traditional ones. Due to globalization and wealth caused by oil export, urban planning strategies, Western architectural principles, construction materials and technology have been imported and are currently threatening Islamic culture and traditions [1-11]. Nowadays continuity with Islamic cities' urban fabric has been neglected in the rush for 'westernized' developments. Scholars argue that most of modern buildings erected in Middle Eastern cities are alien to the local culture: these buildings contribute in creating an unfamiliar environment within Arab cities [5,12,13].

Over the past years, Doha, the capital city of Qatar, has grown economically as well as physically. Also, the rapid and extensive development of the built environment of the city has been prompted by international sport events: the World Youth Cup (1995), the West Asian Games (2005), and the Asian Games (2006).
Major changes to the built environment of Doha have been caused by the construction of infrastructural and large-scale urban and architectural projects, planned and currently under construction for the foreseen 2022's World Cup. Also, Qatar is currently making large investments in urban public transit systems (for example the Doha metro, the Lusail LRT (light rail transit) and BRT (bus rapid transit)), which will contribute to further developments around/along the major train stations [14-17].

The urban fabric and built forms of Doha display equilibrium between traditional and contemporary architecture, where several heritage buildings, characterized by Qatari architectural vernacular elements, are as magnificent as those built with a modern architectural language.

The traditional architectural designed district such the Souq Waqif represents the core of traditional built heritage and local culture. Not far from the Souq Waqif, the new business district of West Bay, enclosing many modern buildings unlike the heritage district of Doha, is the physical built-image of globalization and westernization.

Some of the tallest skyscrapers in Qatar are found in this area, such as the $\mathrm{Al}$ Quds Endowment Tower or the Burj Qatar, looking spectacular from 'The Corniche', which is simple sea-front green linear link, which connects the Old Doha or the Souq Waqif ('Old Doha') to the New Doha or West Bay [18-20].

This paper discusses how and the extent to which both (A) the district of West Bay, which is the most contemporary development and one of the most dominant districts of Doha and (B) the traditional district of the Souq Waqif, known as the most prominent heritage site displaying the traditional local built-cultural identity, contribute to enhance quality of life and/or livability. 


\section{Background}

\section{Qatar: urban growth and planning challenges}

Over the past decade, Qatar, recognized as 'one of the most important producers and exporters of Liquefied Natural Gas (LNG) in the world, has witnessed a wealth, which has contributed to a rapid and significant urban growth and/or to a new form of urbanism. In turn, this has prompted the development of various new forms of urban typologies, such as iconic skyscrapers, waterfront glass towerhotels, cultural and educational urban facilities [15].

Doha is currently attempting to be recognized as a service hub in the region. This means that the city is putting a tremendous effort to attract international companies to open their businesses within the local reality of Qatar. This current strategy would allow Qatar to differentiate its economy, currently and mainly based on the dominant export of Liquefied Natural Gas (LNG). In turn, liberalization and decentralization are measures needed to attract investors in Qatar Currently large-scale investments and mega-projects are under development and contribute to reshape new urban morphologies within the city [21].

As a result, urban planners and policy-makers are addressing the need for combining smart-fast growth and consolidation of strategies to not have an urban fabric developed simply under the pressure of speculators and developers, where the built environment is reduced to become a temporary venture. One of the major challenges is to develop a city where aspects of livability, sustainability, heritage, identity, culture are integrated within the need of the city to become an international service hub in the GCC. In light of this objective, authorities support a balanced urban growth, encouraging (1) the privatization of sectors of the city allowing fast urban growth and, at the same time, (2) the development of areas consolidating the country's built cultural identity. Therefore, the country is experiencing a 'conflict between a rapid urban development, which seeks to integrate historical and traditional contexts, and the continual import and impact of globalized morphologies' [15].

\section{West Bay: globalization and livability}

In 1975 Qatar's government commissioned the American urban planning firm W.L. Pereira Associates to draft a master plan for the development of the North District of Doha (NDOD), West Bay [22]. The district, of West Bay, or Dafna, attracted large investments from the government and from private institutions. Currently, within the West Bay Financial District, more than fifty high-rise towers have been constructed; where nearly one third exceed the height of 150 meters. Most of them are located along the waterfront area. This recent development has changed the morphology of Doha, transforming the city from a low-rise to an impressively vertical built environment. Currently ministries, public, semi-public organizations and hotels and residencies occupy the commercial high-rise buildings. A few government buildings are erected as modern landmarks within the district.

At current, West Bay, with its imposing futuristic skyline and modern high-cost, high-density, high-rise mixed-use towers and skyscrapers is the dominant iconic cityscape-image of contemporary architecture and urbanism in Doha. This modern cityscape is a source of attraction for foreigner international companies looking for an arena where to open their headquarters and enter the local market.
Previous studies have highlighted that the district often offers its inhabitants the opportunity to reside in the vicinity of their places of work. Reducing the distance between housing and workplaces has a substantial effect on enhancing livability because it contributes to (1) saving time on travelling, (2) to reducing traffic congestion, (3) to saving expenses for transportation $[19,23]$.

On the other hand, the neglected combination of integrated commercial and residential facilities, namely seen the density of the district is seen as a negative factor. A mix of commercial facilities such as restaurants or storefronts at the ground floors of buildings is also missing. The mixed-use pattern would encourage residents to walk and convenience shopping. Besides, walkability would contribute in decreasing the use of automobile, reducing further traffic congestion, and finally contribute to enhance livability within the area.

In addition, the study reveals that the district lacks to infuse a sense of community because of the absence of public spaces, which are the arenas for social interactions. Livability is enhanced by public open spaces, lively streets, landscaped plazas, street furniture and various public-realm amenities, which would help to animate the neighborhood [24-27]. Additionally, a sense of belonging to the community can be enhanced through public spaces. This study reveals that open public spaces have been replaced by private gated car-parks surrounding the buildings.

The district of West Bay, which encloses several urban areas and towers currently under construction, is a district not conceived for cyclists or pedestrians, but for car drivers. One of the claimed challenges is to go around buildings by foot, seen the lack of a pedestrian network, footpaths and sidewalks. Therefore, pedestrians are forced to walk besides the streets. It is required to install shaded street furniture, to implement footpaths, to plan safe pedestrian crossings or crosswalks. This intervention would allow to making the community more livable. Significantly, the study reveals that West Bay is highly appraised as a very safe district, namely when compared to several European cities, from where residents move $[15,18]$.

\section{The Souq Waqif heritage site: cultural heritage and livability}

The heritage site of the Souq Waqif, located within the Msheireb's district, in the vicinity of the Cornice and of the Museum of Islamic Art, encompasses an area of 164,000 square meters. As anticipated, Souq Waqif (Down Town Doha) enclosing vernacular buildings designed with traditional architectural forms and elements, display the built heritage of Qatar [18,23].

The Souq Waqif was a labyrinthine market located in the vicinity of the city's waterfront, built in the 19th century to host the commerce of primarily livestock goods. 'Souq Waqif' means "standing market" in Arabic, in reference to a gathering place positioned around the riverbed 'Wadi Msheireb'. Various sorts of sub-markets for wholesale and retail trades, with high walls' buildings, wooden portals and small windows, open air stalls for local vendors were enclosed in the area. Therefore, locals and Bedouins would stop to trade goods of various sorts, from sugar, salt, cumin, turmeric, clothes, coal, and wood. Also, fishermen used to gather at the Souq to trade fish [20].

In the 1970s, due to the development in Doha of other urban villages, the market became desolated. It was in 2006, due to a restoration and renovation project, that the urban fabric and buildings within the heritage area were renovated with the aim of conserving the traditional Arab building and historical identity. Qatar's Emir Sheikh Hamad bin Khalifah al Thani and his wife Sheikha Moza bint Nasser 
founded the restoration of the entire area. Thanks to the intervention PEO-Private Engineering Office of the Emiri Diwan, the Souq was resumed its original image and kept its functions. In addition new restaurants, cafes, art galleries were inserted within the Souq Waqif, which was then completed in 2008. Currently, the Souq Waqif is the physical embedment of the national objective and ambition of preserving the built heritage and culture of Qatar [20].

The Souq Waqif is dominated by one main street, with cafes, restaurants, small shops and alleyways acting like gateways to a labyrinth of corridors, which are not just means of connection, but contribute to the identity of the heritage area. These corridors, ranging from wide to narrow, covered and exposed paths, are naturally ventilating 'sikkas'. The heritage Qatari buildings' facades remind of the main character and cultural identity of the Souq Waqif.

Visitors consider traditional and Arabic restaurants and cafes ideal public areas for social interactions. Usually in summer time fans and mist sprayers located in the open areas of restaurants and cafes contribute to provide cool breeze to the customers dining outside. In the winter months, social-entertainment events such as cultural performances, festival and concerts take commonly place. These various activities contribute to enhance livability within the site. In addition, the study reveals that the installation of urban furniture (utilitarian and decorative), public sun-shaded benches where people might publicly and freely seat, green areas and/or planting on streets and open areas of the Souq Waqif, would further contribute to enhance social activities and/or livability [28-31].

\section{Conclusions}

Skyscrapers or high-rise buildings were firstly conceived and erected in the United States. Then, seen the growth of population and shortage of metropolitan land within cities, this trend became popular in many world-widely metropolis. Nowadays, skyscrapers are the image of globalism and economic prosperity and world-widely cities are embracing rapid urbanization where urban developments are characterized by high-rise buildings as dominant typology. The image of high-rise buildings dominating the skyline of cities is the new identity-maker of contemporary cities, which world-widely compete for the highest and/or most luxurious tower. Scholars stress that the integration between tall buildings and the ground level is often neglected. West bay could represent a manifestation of this contemporary trend, seen how the ground floor of the towers is characterized by security gates and parking areas, rather than public realm spaces. This pattern has a negative impact on the settlement's livability and/or quality of life because it reduces the accessibility of users to the area and deprives the users of spaces utilized for social activities. This states that iconic high-rise typologies, as main outlines of noticeable skylines, are not enough to enhance livability within cities [18].

In opposition to build environments created under the western pressure of globalization, "traditional" or "vernacular" settlements typically pedestrian oriented and located in older areas of cities, facilitates residents to perform daily activities without the use of a car. As shown from the case study of the Souq Waqif in Doha, 'traditional' neighborhoods have places of worship, small shops, coffee shops and/or restaurants within walking distance. Therefore, walking is encouraged because by this stetting, because pedestrians are not forced to walk across parking lots or to compete with cars along busy highways (as for example shown in the case study of West Bay). Users' level of social interactions and thus livability is affected by the spatial form of the urban fabric: in opposition to West Bay, users within the Souq Waqif are encouraged to be socially involved, also facilitated by the pedestrian oriented and mixed-use settlement $[20,32]$.

Urban planners and designers, planning the contemporary development of the built environment, should not neglect the users' daily socio-cultural needs. Scholars stress that contemporary urban developments should be seen as a product of sociological, cultural and historical contexts and not just as manifestation of investments, emphasizing the globalization political-economic phenomenon or trend, where cities compete to attract investors allowing the construction of new building typologies, such as residential high-rise towers, waterfront developments and new urban landscapes [33,34].

Cities witnessing a fast and rapid development and/or growth often experience the development of settlements planned under speculative and standardization purposes. In addition, as scholars highlight, over the last years the built environment of cities has been planned differently from traditional or vernacular settlements, which have a positive effect on users' social interactions and/or livability. In opposition, the recent trend has been to develop westernized neighborhood designed without consideration of users' way of life, culture and socialization needs and/or where the livability aspect is neglected [14,35].

The difference into the way the built environment contributes to enhance livability has been analyzed within the modern and traditional districts of Doha: West Bay and the Souq Waqif. It is hoped that the body of knowledge shown by this study, namely the dialectic relations between the city's need for modernization while enhancing livability and consolidating cultural urban identity, could contribute to shape an integrated urban planning strategy for establishing Doha as the cultural and economic hub of Middle East.

Planning the urban fabric of new districts and communities should be pursued with the purpose to enhance users' quality of life and/or livability, of which, as Qatari Architect Ibrahim Mohamed Jaidah stated in his book 'The History of Qatari Architecture', traditional buildings and urban settlements give a clear glimpse of 'Traditionally, in the old architecture of Qatar the urban development of cities and villages was based on the creation of agglomerations of housing units. These agglomerations were the essence of traditional Qatari architecture, which can be defined as architecture of social values.

Historically, Qatari architecture has developed from the requirement to satisfy different social factors such as religion, privacy and the extended family. In addition to these, the climate also played a major role, dictating the overall shape of the buildings, their facades and openings' [36].

Modernization is not a negative term adopted to depict or define an architectural movement or style. Modernization is a term adopted to define the architectural style related to contemporaneity.

The development of architectural and urban environments should be based on the consideration that the built environment is designed and plan to accommodate people needs and culture, as a way of life, which continuously evolves and changes.

The design and planning process should not simply obey to speculative purposes of multi-national corporations, as nowadays happen in several urban international contexts. 


\section{Future Research Opportunities}

This study has explored the spatial form of the modern and the traditional settlements of Doha, namely the way the specific built environments of West Bay and the Souq Waqif contribute to enhance livability. The way and the extent to which modern and traditional building typologies can in turn contribute to the implementation of livability of cities and consolidation of cities' urban identity might be further explored. Therefore, further studies analyzing in detail the extent to which building typologies are tools for cultural identity and livability could be engaged [37].

\section{Acknowledgement}

The author would like to acknowledge the support of Qatar University for creating an environment that encourages scientific research. Also, the author would like to express his gratitude to the Government of Qatar, especially to the Ministry of Municipality and Urban Planning (MMUP), the Qatar National Council for Culture, Arts and Heritage, Qatar Rail and Ashghal Governmental Agencies of Doha for their kind assistance and collaboration - for handling relevant visual data and cardinal documents supporting the purpose of this research study. Finally, the authors thank the anonymous reviewers for their comments, which contributed to an improvement of this paper.

\section{References}

1. Gehl J (1987) Life Between Buildings: Using Public Space. Van Nostrand Reinhold, New York.

2. Oliver P (1997) Encyclopedia of Vernacular Architecture of the World. Cambridge University Press, New York.

3. Oliver P (2003) Dwellings: The Vernacular House World Wide. Phaidon Press, London.

4. Oliver P (2007) The Vernacular House World Wide. Phaidon, London.

5. Petruccioli A (2007) After Amnesia-Learning from the the Islamic Mediterranean Urban Fabric. Grafica \& Stampa, Italy.

6. Putnam RD (2000) Bowling Alone: The Collapse and Revival of American Community. Simon \& Schuster, New York.

7. Rapoport A (1969) House, Form and Culture. Prentice-Hall, New Jersey.

8. Rapoport A (1984) Vernacular Architecture and the Cultural Determinants of Form. In: King AD (ed.), Buildings and Society: Essays on the Social Development of the Built Environment. Boston and Henley: Routledge \& Kegan Paul, London.

9. Rapoport A (2000) Culture and built form: A Reconsideration. In: Moore KD (ed.), Culture - Meaning - Architecture: Critical Reflections on the Work of Amos Rapoport. Ashgate Publishing Company.

10. Salama A (2013) The Impact of Economic Diversification on Urban Morphologies in Doha: An Interdisciplinary Assessment. Qatar Foundation Annual Research Forum Proceedings, Qatar.

11. Sarup M (1994) Home and Identity. In: Robertson G, Mash M, Tickner L, Bird J, Curtis B et al. (eds.), Traveller's Tales-Narratives of Home and Displacement. Routledge, New York p: 93.

12. Falahat S (2014) Re-imaging the City-A New Conceptualisation of the Urban Logic of the "Islamic city". Springer Vieweg, US.

13. Hakim BS (2013) Arabic Islamic Cities: Building and Planning Principles. Routledg, UK.
14. Adham K (2008) Rediscovering the Island: Doha's urbanity from pearls to spectacle. In: Elsheshtawy Y (ed.), The evolving Arab City: tradition, modernity and urban development. Routledge, UK.

15. Salama A, Wiedman F (2013) Demystifying Doha. Ashgate Publishing Limited, UK.

16. Shaaban K, Radwan E (2014) Rebuilding the Transportation System in the City of Doha. Journal of Traffic and Logistics Engineering 2: 241-247.

17. Wiedmann F, Mirincheva V, Salama AM (2013) Urban Reconfiguration and Revitalisation: Public Mega Projects in Doha's Historid Centre. Open house international 38: 27-36.

18. Furlan R (2015) Liveability and Social Capital in West Bay, the New Business Precinct of Doha. Arts and Social Sciences Journal 6: 1-11.

19. Furlan R, Almohannad M, Zaina S, Zaina S (2015) Integrated Approach for the Improvement of Human Comfort in the Public Realm: The Case of the Corniche, the Linear Urban Link of Doha. American Journal of Sociological Research 5: 89-100.

20. Furlan R, Faggion L (2015) The Souq Waqif Heritage Site in Doha: Spatial Form and Livability. American Journal of Environmental Engineering 5: 146-160.

21. Jodidio P, Halbe R (2015) The New Architecture of Qatar. Skira Rizzoli, New York.

22. Rizzo A (2014) Rapid Urban Development and National Master Planning in Arab Gulf Countries, Qatar as a Case Study. Cities 39: 50-57.

23. Furlan R, Nafi S, Alattar D (2015) Built Form of the Souq Waqif in Doha and User's Social Engagement. American Journal of Sociological Research 5: 73-88.

24. Brown LJ, Dixon D, Gillham O (2014) Urban Design for an Urban Century-Shaping More Liveable, Equitable, and Resilient Cities. John Wiley \& Sons, USA.

25. Kaspirin R (2011) Urban Design-The Composition of Complexity. Routledge, USA.

26. Lang J (2005) Urban Design - A Typology of Procedures and Products. Routledge, United States.

27. Saliba R (2015) Urban Design in the Arab World: Reconceptualizing Boundaries (Design and the Built Environment). Routledge, US.

28. Day K (2003) New urbanism and the challenges of designing for diversity. Journal of Planning Education and Research 23: 83-95.

29. Givoni B (1989) Urban Design in Different Climates: World Metereological Organization Publication.

30. Hamilton-Baillie B (2004) Urban Design: Why dont We Do it in the Road? Modifying Traffice Behavior through Legible Urban Design. Journal of Urban Technology 11: 43-62.

31. Montgomery C (2013) Happy City: Transforming Our Lives through Urban Design. Farrar, Straus and Giroux, New York.

32. Furlan R, Muneerudeen A, Khani FA (2016) Urban Revitalization of Public Spaces in the Pearl in Qatar. American Journal of Sociological Research 6: 1-9.

33. Farr D (2008) Sustainable Urbanism - Urban Design with Nature. Wiley, United States.

34. Zyscovich B, Porter DR (2008) Getting Real about Urbanism : Contextual Design for Cities. Urban Land Institute, Washington.

35. Elsheshtawy Y (2004) Planning Middle Eastern Cities. An urban kaleidoscope in a globalizing world. Routledge, London.

36. Jaidah I, Bourennane M (2010) The History of Qatari Architecture 1800-1950. Skira, Italy.

37. Amit-Cohen I (2005) Synergy between Urban Planning, Conservation of the Cultural Built Heritage and Functional Changes in the Old Urban Center-The Case of Tel Aviv. Land Use Policy 22: 291-300. 